\title{
TREATMENT TECHNOLOGIES OF PRODUCED WATER FROM OIL AND GAS EXTRACTION: A REVIEW
}

\section{${ }^{*}$ Anaheed S. Hameed ${ }^{1}$}

1) Environmental Engineering Department, College of Engineering, Mustansiriyah University, Baghdad, Iraq

\begin{abstract}
Exploration and production of oil and gas are two operations that have the ability to damage and polluted the environment. The most significant waste created by these operations is produced water. Since the produced water includes toxic pollutants in both organic and inorganic compounds, produced water from oil and gas extraction cannot be discharged directly into the environment. Uncontrolled discharge can cause damage to the environment, including the loss of marine and plant life. Until being discharged into the environment, the produced water must be treated to meet the quality requirements. This article reviewed the sources, characteristics, and extent of pollution caused by oil and gas producing water, as well as different technologies for treating or disposing it. Physical (absorption, membrane filtration etc.), chemical (oxidation and sedimentation) and biological processes can all be used to treat the produced water (activated sludge, biological air filters etc.) Because no single technology can satisfy the acceptable effluent properties, two or more treatment systems can be used in a sequential process.
\end{abstract}

Keywords: produced water; treatment technologies; physical treatment; chemical treatment; biological treatment.

\section{Introduction}

The world is increasingly facing with a number of crises, including environmental damage $[1,2]$ Fresh water demand [3] and renewable sources of energy [4]. According to Drioli et al. [5] several countries of the world continue to depend on oil products as a primary source of electric power and transportation etc. $[6,7]$. The rising of global demand for oil and gas, the need to exploit reserves that contain gas and oil has emerged. As a result of the exploration and production processes, produced Water is a byproduct of this operation. Produced water, which is the most significant by-product of oil and gas exploration and development [8]. Produced water from oilfields is a byproduct of hydrocarbon production from underground reservoirs which is usually produced through petrochemical-based fuel processing, petroleum power generation, and some industrial activities $[9,10]$. The water stored in underground formations that reaches the surface of oil and gas is referred to as produced water. This water may include reservoir water, injected water into the formation, and any chemicals additive applied during the production and treatment processes [11].

Since PW is found in hydrocarbon-bearing formations, it is a complex combination of nonpolar and polar organic elements, as well as inorganic cations such as magnesium, calcium, and iron, and anions such as carbonate and bromide sulfate, as well as heavy metals (such as barium, plutonium, cadmium, chromium, and lead) [12] and natural radioactive materials.

*Corresponding Author: Anaheedsaad61@gmail.com 
With varying geographical formations and geographical location of oil and gas reserves, the percentage of these contaminants ranges from one oil field to another. These produced water components are usually toxic to the environment. As a result, attempts are being taken to treat produced water and recycle it for other uses, such as re-injecting it into wells to preserve oil productivity (remaining oil and suspended solids should be removed). Or reuse for agriculture after meeting the requirements needed for this purpose, and using them in industry is a productive way to deal with them.

Iraq's oil fields are dispersed through large swaths of land. In some mature oil fields, particularly in Iraq's southern and northern, the water-to-oil ratio can approach $20 \%$. In the near future, this ratio could approach the global average [13]. Water injection is becoming increasingly necessary in some Iraqi oil fields in order to sustain oil and gas productivity, so the amount of this water is continuously rising. Iraq is one of the countries that can benefit from related water production. Iraq is now one of the world's three leading countries in terms of crude exports and reserves.

Approximately 75percent of Iraq's overall oil reserves are concentrated in the giant oil fields of the southern governorates, with upwards of $55 \%$ distributed in and around Basra Governorate [14]. The quantity and quality of available water supplies in this area are increasingly declining, while demand is growing due to population growth and economic development, necessitating the search for alternative resource [15].

In Iraq, an average of 1 billion barrels are produced for every 5 billion barrels of oil. The current water / oil ratio is estimated at 1: 5 [16], while in the USA, the current water / oil ratio is 10: 1, with an annual total of about 3 billion barrels, and this is according to some estimates the largest volume of waste water In the United States of America [17].

The amount of produced water generation rises with the age of the well rises and gas and oil production declines [18]. Water/oil ratio during oil extraction is approximately 3:1 [19]. Despite the fact that the ratio has improved, the produced water global production remains at $39.5 \mathrm{Mm}^{3}$ per day. Because of well ageing, it is similarly predicted that the water/oil ratio for crude oil resources would average 12 (v/v) by 2025[19-21]. As a result, the market for the controlling and re-use of produced water is predictable to expand more.

The characteristics of produced water in general, its environmental and health impacts, and the physical, chemical, and biological techniques applied to treat it are all discussed in detail in this review paper.

\section{Produced Water Characteristics}

PW is not a single product; it also has a simple to complex composition and is a mixture of dissolved and particulate organic and inorganic compounds. The physical and chemical characteristics of produced water differ greatly depending on a number of factors, including the field's geographical region, the depth and age of geological formation, hydrocarbon geochemistry, the exploration technique, type of produced hydrocarbon and its chemical composition of reservoir. Produced water toxicity discharged from gas platforms is ten times that of oil well discharge. Furthermore, the volume of oil produced is much greater than the volume of gas produced [22]. Because the features of each region differ, explicit studies with each country should also be conducted, and such studies may also aid in studying the environmental hazards of its discharge. Table 1 categorizes and summarizes the major 
components contained in produced water. In general, the main constituents found in PW contain: total dissolved solids (TDS) or electrical conductivity, salt content (salinity), polyaromatic hydrocarbons (PAHs), oil and grease $(\mathrm{O} \& \mathrm{G})$, toluene, benzene, ethylbenzene, toluene, xylenes (BTEX), organic acids, phenols, natural organic \& inorganic compounds that source of scaling and hardness (e.g., magnesium, calcium, barium and sulfates) and chemical additives like anti-microbial agent and corrosion inhibitors which are used throughout well's drilling, cracking, and operation [23].

Table 1: characteristic of produced water from oil field [24].

\begin{tabular}{llll}
\hline Parameter & Value & Heavy metal & value \\
\hline Density & $1014-1140$ & Calcium & $13-25800$ \\
PH & $4.3-10$ & Aluminum & $310-410$ \\
Surface & $43-78$ & Sodium & $132-97000$ \\
tension & & & \\
TOC & $0-1500$ & Potassium & $24-4300$ \\
COD & 1200 & Magnesium & $8-6000$ \\
TSS & $1.2-1000$ & Iron & $<0.1-100$ \\
Total oil & $2-565$ & Boron & $5-95$ \\
Chloride & $80-200000$ & Cadmium & $<0.005-0.2$ \\
Sulfate & $2-1650$ & Chromium & $0.02-1.1$ \\
Phenol & $0.009-23$ & Manganese & $<0.04-175$ \\
Sulphide & 10 & Lead & $0.002-8.8$ \\
\hline
\end{tabular}

*All units in $\mathrm{mg} / \mathrm{l}$ except density in $\mathrm{kg} / \mathrm{m}^{3}$ and surface tension in dynes/cm and $\mathrm{PH}$ unitless

\section{Management of produced water}

The produced water is described as liquid waste from the oil and gas fields, and its management is expensive. Three levels of pollution prevention are included in produced water management:

1. Using methods to minimize the amount of water produced

2. Recycling and reusing
3. If none of these levels are feasible, the final alternative is to discharge it into the environment [25].

Some alternatives for oil and gas operators to handle produced water have been proposed [26].

1. Injection: The injection of water produced in the same formation as oil produce.

2. Drainage: The treatment of produced water in order to comply with onshore or offshore drainage legislation.

3. Reuse in gas and oil operations: treating produced water to make it suitable for use in typical oil and gas field operations.

4. Beneficial use: treatment of produced water to satisfy desired quality for useful purposes such as irrigation [27], pasture rehabilitation, livestock and animal consumption and drinking [28].

\section{Environmental and Health Effects of PW and Regulation}

Produced water contains contaminants that can cause damage. If used for irrigation, it poses a threat to aquatic life or plants $[29,30]$.Aromatic hydrocarbons such as polycyclic aromatic hydrocarbons (PAHs) and alkylated phenols are mutagenic and carcinogenic to humans and animals, can increase biological oxygen demand (BOD), are toxic to aquatic organisms, and can cause cancer in humans and animals [31]. Effects are unlikely to arise until the amount of an absorbed constituent by an individual exceeds the set threshold.

Produced water contains organic components, heavy metals and chemicals that have a toxic effect when they are discharged into surface waters. These hydrocarbons have the potential to accumulate in marine organisms. This

accumulation can lead to changes in living organisms at physiological or biochemical levels that have immediate adverse effects on 
living organisms [32].The produced water treated by conventional methods by gravity separation, discharged into the environment, or re-injected into wells, and although it must meet certain standards, this causes pollution to soil, surface water, and groundwater [33].

The chemicals from hydraulic fracking operations had 6 to 14 health impacts. These effects included sensory organ damage, cancers, reproductive toxicity, gastrointestinal and liver disease, as well as brain and nervous system damages [34]. Since produced and flowback water contain candidate endocrine disruptors, disposal of this wastewater is a major concern [35]. New York has record that the fracturing fluids contain formaldehyde, acids, and a variety of other toxic chemicals [36].

So many countries are beginning to introduce stricter regulatory requirements for discharging produced water into surface water. The maximum volume of oil in disposed produced water (OIW) set by the Oslo Paris Convention (OSPAR) is $30 \mathrm{mg} / \mathrm{l}$ [37]. Offshore discharged of oil and grease in produced water is allowed in Australia to be $30 \mathrm{mg} / \mathrm{l}$, while the Republic of China sets monthly average limits of oil and grease at $10 \mathrm{mg} / \mathrm{l}$ [33].

\section{Produced Water Treatment Technologies}

Studies identifying, verifying, and compiling existing and newly developed technologies show the economic advantages of treating produced water. Treatment of produced water is an efficient choice because it converts it from a liquid waste that causes environmental damage to a valuable product. The treatment options are mainly determined by the quality of the water and the ability to meet the regulatory limits set for the purposes for which it is reused. When deciding whether to drain the produced water into the surface water, it must be conditioned so that it meets surface water requirements, such as the concentration of ammonia and barium, which causes toxicity to animals and susceptible plants. In general, when transporting this water for any purpose, it must be assured that it complies with the usage requirements. Chemical (for example, TDS), physical (temperature), or biological (coliform bacteria / liter) standards are possible. The treatment goals will be decided by the standards, regulatory constraints, and volume generated [26]. The following are the overarching objectives of produced water treatment:

1. Removal of oil and oils from the produced waters.

2. Removal of soluble organic matter and dissolved organic matter.

3. Remove bacteria, micro-organisms, algae, etc.

4. Remove suspended particles, sand and turbidity.

5. Removal of light hydrocarbon gases, carbon dioxide, and hydrogen sulfide.

6. Removal of dissolved salts, sulfates, nitrates, and pollutants.

7. Remove excess water hardness.

8. Adjustment of the sodium absorption rate (SAR) by adding calcium or magnesium ions to the water produced to adjust the sodium levels before irrigation.

9. Removal of natural radioactive materials (NORM).

\subsection{Physical Treatment Technologies}

\subsubsection{Adsorption}

This technique is regarded as one of the better handling methods for achieving the highest possible water quality because it can decrease concentrations to the lowest possible levels [38].

According to Spellman [39], the adsorption process will recover approximately 100 percent of the produced water and remove 85 percent of 
heavy metals. The primary difficulty of using this method is the expense of installing and maintaining the system; however, this disadvantage can be avoided by using more cost-effective absorption media, for example activated carbon, which can improve this process. Another difficulty of adsorption process is the need to dispose of wastes and expended media through the media regeneration process.

Factors impact on adsorbent performance.:

- $\quad$ Temperature and $\mathrm{pH}$

- $\quad$ dispersed Oil

- low concentrations heavy metal and organic metal complexes.

- Pollutants dissolved in water (organic chemicals).

- High salinity [40].

Okiel et al. [41] examined the efficacy of using bentonite and deposited carbon powder activated-carbon (PAC) to remove oil from PW, and the findings revealed that increase the contact time and quantity of the adsorbent leads to a rise in the percentages of oil removal. This emphasized the significance of contact time in adsorption technology.

Luukkonen et al. [42] investigated the removal of total organic carbon (TOC) from water power plant using four commercial types of activated carbon. For the experiment, continuous flow activated carbon filters were used in the steam boiler desalination plant. After 30 days, the findings showed that all tested activated carbon had a comparable removal effectiveness of 4245 percent of total organic carbon and 58-68 percent of dissolved organic carbon. Total organic carbon removal efficiencies remained constant throughout the experiment, ranging between 41.6 and 44.8 percent for all kinds of activated carbon used, and TOC residues after filtering the activated carbon were between 126 ppb and $260 \mathrm{ppb}$.

To remove oil from the produced water, [43] used a filter made of black walnut husks or pecan nuts (the middle is granular). The oil droplets were infiltrated into the filter layer, where the highest 18 in of the layer gave 99 percent of the oil removal, and it was noted that the medium was completely saturated as the flow rate was tested across the unit area of the filter that ensures the best removal of oil (the saturation percentage depends on the concentration of oil entering the medium). Within 20-30 hours at a depth of 48 in.

Organic nanotubes (ONTs), which are formed by self-synthesis of peptide lipids, were used [44] as an adsorbent for treatment produced water, with the concentration of $\mathrm{Pb}^{2+}$ in the laboratory prepared form of the produced water being reduced to $0.04 \mathrm{ppm}$ when treated with ONTs, compared to $0.84 \mathrm{ppm}$ when not treated with ONTs. Adsorption experiments with real product water revealed that ONTs could absorb heavy metals, suspended solids, oil, and certain organic compounds in produced water in a onestep process without any pre-treatment.

Chitosan activated montmorillonite (CTS-AMMT) was synthesized from shrimp shells and acid-activated montmorillonite as a low-cost biological adsorbent, and it was used [45] to eliminate five different kinds of positive and negative minerals. Crude oil is derived from both manufactured and natural produced water in oil fields. The adsorption data showed that the CTS-A-MMT material absorbed crude oil and all investigated minerals (except As), and when the bio-compound was tested to extract crude oil and heavy metals from processed and real produced water, the bioabsorbent material achieved a removal 
efficiency of 65 to 93 percent for minerals and 87 percent for crude oil.

\subsubsection{Flotation}

Fine gas bubbles have been used in this method to separate suspended solids which Sedimentation would not remove it. This method involves gas injection into the water to be treated, then allowing suspended particles and oil droplets to adhere to the gas bubbles and float to the surface, resulting in the formation of a foam that is removed by skimming. This technique can be used for nitrogen, air or other inert gases. This approach may be used to remove volatile organic material. oil from PW [8].

Dissolved gas flotation (DGF) and induced gas flotation (IGF) are two types of gas flotation techniques that vary in the procedure used to produce gas bubbles and the size of the resulting bubble. The method effectiveness is primarily determined by the contaminants to be removed, the difference in fluid density, temperatures, and the oil drop size. This process doesn't perform perfectly at high temperatures, but it works well at low temperatures which can be used to treat water with low and high total organic carbon (TOC) concentration, as well as water polluted with oil \& grease, and solid particles in amounts less than $7 \%$ [46].

The dissolved air flotation process should remove particles as small as $25 \mu \mathrm{m}$, and when coagulation is used as a pretreatment step, toxins as small as 3-5 m may also be removed. According to Fakhru'l-Razi et al. [33] a gas flotation process has several advantages and disadvantages. Among the benefits are: (1) It is easy to use; (2) it has no moving components. The drawbacks are as follows: (1) it requires a significant amount of air to be produced; (2) the volume of foam generated on the surface; and (3) a 4-5minute detention period.
Using the flotation process, an oil removal rate of 93 percent was attained [47]. Furthermore, Beyer et al. [48] used induced air flotation as a pre - treatment of produced water for oilfields containing a ratio of $20.000 \mathrm{mg} / \mathrm{l}$ dissolved solids and discovered that the level of TOC and COD was reduced to $115 \mathrm{mg} / \mathrm{l}$ and $595 \mathrm{mg} / \mathrm{l}$ respectively.

Thus, the content of oil, volatile organic compounds, and suspended solids can be measured using these methods. It is possible to remove it from the produced water without the use of extra chemicals. Coagulants should also be used to improve processing efficiency in other cases. The biggest drawback, however, is that the sludge is disposed of at the treatment end, which raises the treatment cost [49].

\subsubsection{Filtration}

A comparatively simple method used for treatment of wastewater and water that depends on the use of media that constituent porous filter to let only water and prevent impurities to pass through it. Crushed stone, activated carbon and sand are just a few examples of porous substances suitable for use as filter media. On the other hand sand, is the most commonly used material because of its availability, effectiveness and low cost [50].

According to Adewumi et al. [51] , demineralization should be accomplished through a sand filtration process following a three-step pre-treatment stage: (1) adjusting the $\mathrm{pH}$; (2) rising the concentration of oxygen in the reactions through the ventilation unit (3) The contact time should be long enough to allow the solid precipitated substances in the solids separation unit to stabilize. Sand filtration can be used to remove the fine solids that not separated during the pre-treatment steps.

The removal of different ions from water via sand filtration was studied by Wathugala et al. 
[52]. Sand filtration was found to remove more COD and nitrogen, and the filtered water is free of ammonia and phosphorous. Cha et al. [53] introduced a new sand filtration method that was combined with ozone technique to treat the produced water. This strategy assisted in lowering the oil content to $20 \mathrm{mg} / \mathrm{l}$ and the COD from $320 \mathrm{mg} / \mathrm{l}$ to $102 \mathrm{mg} / \mathrm{l}$. Similarly, sand filtration was used to remove oil and grease from produced water, with 95.8 percent removal achieved [54].

For produced water treatment membrane filtration can also be used, membranes with pore spaces and specific porous classifications that separate the liquid from its constituents selectively. Microfiltration (MF), reverse osmosis (RO), nanofiltration (NF) and ultrafiltration (UF) are the four stable membrane separations [55]. Reverse osmosis separates solute and ionic elements, MF separates suspended particles, UF separates macromolecules, and selective NF separates polyvalent ions [56, 57]. While MF and UF can be used as stand-alone technologies for industrial wastewater treatment, RO and NF are commonly used in desalination.

The membrane technology operates on two types of filtration processes "Fig.1" dead-end filtration (the movement of liquids is perpendicular to the filter surface, and the contaminants trapping on the surface of the filter solidify and form a layer that decreases the filter's performance) and cross-flow filtration (the movement of liquids is parallel to the surface of the filter, and (a layer of particles that is trapped on the surface of the filter is formed While keeping the flow constant).
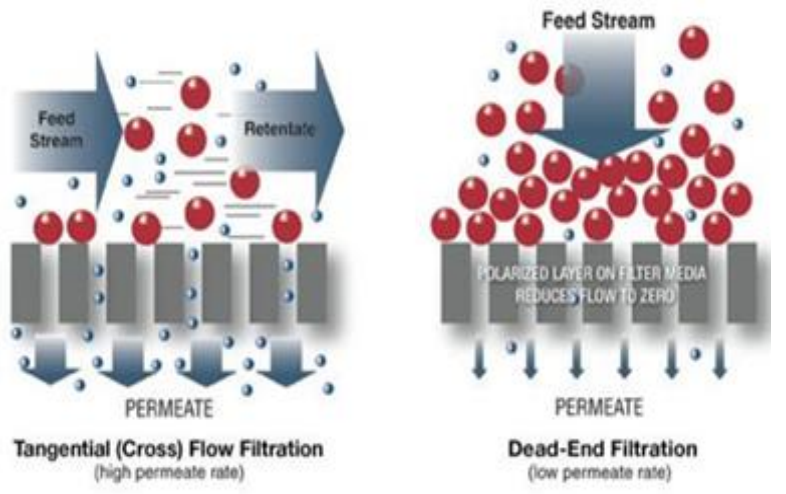

Figure 1. Type of filtration process [58].

Using a non-solvent phase inversion technique, polyether sulfone nanofibers (nanoparticles) composed of $\mathrm{TiO}_{2}$ nanoparticles were developed to improve the properties of pollutant (impurities) inhibitors, water and mechanical properties of real and synthetic produced water treatment [59]. Because of its high oil removal, flow of water, contaminant blocking properties, and mechanical stability, the membrane containing 7 percent $\mathrm{TiO}_{2}$ nanoparticles was the strongest nanocomposite membrane. The developed polyether sulfone nanostructures were prepared and tested in single-stage and double-stage water treatment systems [60].

simple surface oxidation was used to cause a thin layer of water on the surface of a hydrophobic membrane to treat real produced water using membrane distillation (MD) [61]. The stimulation of the enhanced hydrophilic layer was effective in reducing organic pollution, although many of the hydrophilic surfaces caused a polar / electrostatic reaction, resulting in salt precipitation on the membrane's surface.

An electrochemical cell was investigated for the oxidation of the organic materials in natural gas field water using a flux-by-mean of a porous graphite electrode [62]. At a current density of $1.41 \mathrm{~mA} / \mathrm{cm}^{2}$, a maximum removal efficiency of 66.52 percent was achieved. To purify water from oilfields, low-cost PVC / bentonite 
ultrafiltration membranes were prepared and tested [63]. A PVC/bentonite membrane produced the highest permeation flow, and the overall oil recovery was 98.6 percent.

Ceramic membrane pollution in the treatment of produced water from oil fields has been investigated [64]. The characterization, implementation, and efficiency of several ceramic membrane filtration technique is utilized for effective treatment of produced water generated from reservoirs and various oil model systems have been intensively studied.

Membrane distillation crystal (MDC) was used to investigate the recovery of water and minerals from shale gas water [65] Under operational conditions, MDC was successful in recovering water and minerals, with an 84 percent recovery rate of $2.72 \mathrm{Kg} / \mathrm{m}^{2}$ (The optimal).

The numerical simulation of membrane units was used to investigate a dual method of osmotic enhanced dewatering mechanism reverse osmosis (OED - RO) for treating water derived from shale gas [66], the model and experimental results showed that the OED-RO method can be used to concentrate highly saline wastewater while saving energy.

Nanofiltration and reverse osmosis is used in closed circuit desalination to remove TDS and organic material from pre-treated materials [67]. Closed circuit desalination has eliminated up to 99.6 percent of dissolved solids and 89 percent of dissolved organic carbon, meaning that it could be a viable tool for promoting the reuse of produced water.

Over a four-week period, osmosis with reverse osmosis was tested in an experimental scale system to treat produced water from the DenverJulesberg (Colorado) basin [68]. The experimental method accomplished 99 percent removal of all measured ions and 95 percent removal of hydrocarbons.

The backflow and produced water from the Weiyuan shale gas field in China were treated using a hybrid ultrafiltration and reverse osmosis technique [69]. The reverse osmosis method provided water that meets the standards of surface water drainage and irrigation purpose in China under constant pressure 4.5 $\mathrm{MPa}$.

\subsubsection{Hydro cyclone}

A system that uses density difference to distinguish solids (such as sand) and oil contents in produced water. It usually has a cylindrical portion at the top from which the liquid flows transversely and a conical bottom. The power and efficiency of these instruments are affected by the angle of the conical segment [70]. This system has two runoff drains, one at the bottom, known as the downstream or subtraction current, which is used to discharge heavy particles (waste), and one at the top, known as the overflow or product flow, which is used to discharge particles lighter than the input stream (treated water) showed in "Fig. 2".

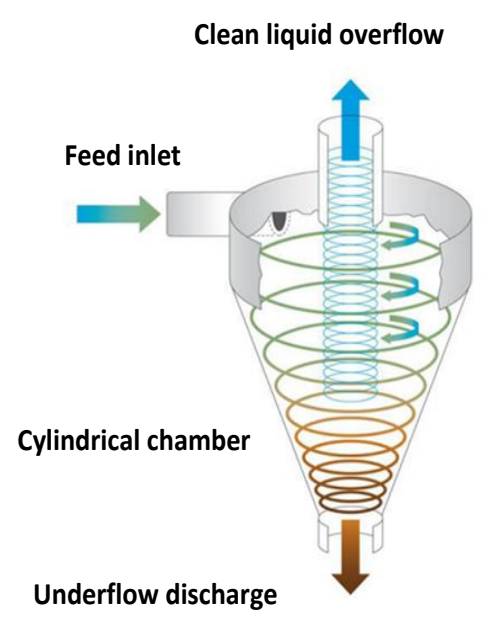

Figure 2. Hydro cyclone device [72]. 
It is capable of removing particles with diameters ranging from 5 to 15 micrometers; however, soluble components cannot be eliminated [71]. These devices have been commonly used to treat produced water by a variety of companies. This approach does not necessitate the use of any chemicals or energy. There are no pre- or post-treatment phases, and the spiral vortex is the only piece of processing equipment available. A large pressure drop through hydro cyclone can occur depending on the device's size and configuration. The waste stream, which is located at the bottom of the hydro cyclone, consists of concentrated solids and is the only residue that must be disposed of

\subsubsection{Electrodialysis}

Electro-dialysis (ED) and electro-dialysis reversal (EDR) are electro-chemical separation methods which are used for salt water treatment, wastewater treatment and seawater desalination, in addition checking for laboratory-produced water treatment [73]. Electrophoresis can be used to isolate the salts found in the resulting water by using selective films made up of a group of positive and negative ions isolated by spacer group plates [74]. After passing water across the membrane beam, an electric current is applied to the cell, allowing the positive and negative ions to travel in opposite directions.

The alternating cells are formed by mixing dilute and condensed solutions between the membranes, where migrating ions selectively intersect with the permeable membrane. Since it occurs under low pressure and can decrease dissolved salts to less than $200 \mathrm{mg} / \mathrm{l}$, this method consumes less energy than reverse osmosis. Electrodialysis is commonly used for water with low TDS levels.

Disadvantages of this technique including its reduced capacity to extract non-ionic components like organic particles, the possibility of membrane contamination, the comparatively expensive, the need for frequent pollutant disposal, and the need for highly skilled labor [73]. Furthermore, while this process may extract salts from produced water, other components such as heavy metals, oil and other contaminants cannot be extracted. below are the primary benefits of this technology: Resistance to harsh environments, estimated membrane life of four to five years, There is no need for specialized infrastructure, and a successful treatment method applied to the produced water [37].

\subsection{Chemical Treatment Technologies}

\subsubsection{Chemical oxidation}

This technology is generally used to eliminate COD, BOD, odor, color, organic material and some inorganic materials from the produced water. According to Igunnu et al. [37], free electrons cannot be existing in the solution, so chemical oxidation mechanism relies on redox reactions since they exist together in the PW. as mentioned by Huang et al. [75], solid oxidants and catalysts may be used to decompose organic impurities present in the produced water. In general, several contaminants can be decomposed by using different oxidants such as ozone, peroxide, ammonia, and oxygen. Besides that, there are several factors that influence rate of oxidation in this technique which include: the dosage of the chemical, the form of oxidizer used, the condition of the raw water, and the contact time between water and the oxidizing materials utilized [37]. The main benefits of this processing process are; It does not require much infrastructure, generates no waste, and does not require any pre-treatment and can obtain a water rate of recovery approximately 100 percent.

however, the key disadvantages are; It has a high cost of chemical, the chemical pump needs 
to be maintained and calibrated constantly and the by-products generated by the process cannot be extracted easily. Moreover, [37] claimed that the final treatment step is needed to extract the particles after oxidation. Advanced oxidation processes (AOP) are a new discovery in the area of water treatment and are an important solution for the rapid oxidation of organic compounds by adding oxidant or mixtures of oxidant [75]. This method uses iron, hydrogen peroxide, and ozone as chemical oxidizing agents.

Additionally, hydroxyl radicals such as titanium dioxide, iron oxide and zinc oxide are also added in this treatment method [76].

The Fenton, ultraviolet (UV) Fenton and ultrasound (US) - Fenton processes have been compared [77] ,for their efficiency in removing organic matter and decoloring water produced from natural gas fields. The Fenton process coupled with ultraviolet (UV) and ultrasound (US) has been developed to enhance the removal efficiency of pollutants. Fenton conditions were optimum after 60 minutes, with molar ratios of 6:1 for $\mathrm{H}_{2} \mathrm{O}_{2} / \mathrm{COD}$ and 25:1 for $\mathrm{H}_{2} \mathrm{O}_{2} / \mathrm{Fe}^{2+}$, respectively, as well as an initial $\mathrm{pH}=3$. Among all these three treatment methods, chemical oxygen demand (COD), total organic carbon, and 5-day biological oxygen demand (BOD5), decolorization efficiency were highest during UV- Fenton (82, 73, 68, 95 percent) followed by US -Fenton (79, 70, 66, and 95 percent) and Fenton (70, 58, 51, 92 percent), respectively. Similarly, a higher biodegradability $\left(\mathrm{BOD}_{5} / \mathrm{COD}\right)$ was observed after the UV-Fenton process (0.76) compared to the other two processes (both 0.73 ).

The graphene nanocomposites $\mathrm{TiO}_{2}$ (rGO$\mathrm{TiO}_{2}$ ) were prepared and tested in treating industrial wastewater [78], containing high salinity levels and different combinations of dissolved organic materials, with the influence of the preparation process on the physiochemical properties evaluated. Using a broad description procedure that combines various analyses such as physical nitrogen adsorption (BET), x-ray (XRD), electron microscopy (TEM), ultraviolet - VIS and reflection spectroscopy (DRUV), and electronic paramagnetic resonance (EPR). The effect of various process variables (e.g., $\mathrm{TiO}_{2} / \mathrm{rGO}$ weight ratios and hydrogen peroxide addition) on photocatalytic behavior was also investigated. The maximum photocatalytic activity was obtained with a $\mathrm{rGO} / \mathrm{TiO}_{2}$ weight ratio of about $10 \%$, suggesting that a strong balance was established between the uniformity of $\mathrm{TiO}_{2}$ particle dispersion on the rGO layers and the degree of surface coverage of the photoactive $\mathrm{TiO}_{2}$ nanostructured materials.

\subsection{2. precipitation}

Precipitation is a typical chemical treatment process for produced water [79]. This procedure will eliminate up and about to 97 percent of colloidal particles and suspended [80]. In the chemical treatment method, flocculants and coagulants mostly composed of inorganic minerals such as magnesium, aluminum polymers and iron are widely used and have been shown to be successful in eliminating contaminants [81]. Other experiments have shown that adding flocculants materials such as anionic polymer and ferric chloride $\left(\mathrm{FeCl}_{3}\right)$ in the flocculation unit can remove minerals, phosphorous, and carbonic compounds; furthermore, these materials were found to be less efficient in removing hydrophobic and nitrogenous compounds [82] . Besides that, it was reported by Zhou et al. [81] that introducing coagulation agents will remove approximately 97 percent of the oil and suspended solids from the PW. Despite these observations, coagulation and flocculation may be used to remove 
suspended and colloidal particles, but not dissolved ingredients. Furthermore, the increased accumulation of potentially toxic minerals in the coagulant sludge may be another disadvantage of chemical precipitation technologies.

\subsubsection{Electrochemical technologies}

The benefits of these technologies over other processing technologies are that they are environmentally friendly, low risk, do not need any extra chemicals, and do not contain discarded materials. Besides, it can remove organic matter efficiently, generate and conserve energy, and assist in the recycling of essential resources from PW deprived of adversely environmental impact. This can be accomplished by integrating multiple electrochemical technology such as water fuel cell electrolysis, electrolysis and photo electrolysis, photoelectric chemistry photocatalysis and photoelectric catalysis into a single electrochemical method [37].

Photolysis is a chemical process that breakdown large particles into smaller particles by using light. According to Fujihima and Honda [83], organic material can be separated from produced water by using $\mathrm{TiO}_{2}$ electrodes for photocatalytic water decomposition [84]. It has been recognized that semi-conductor photocatalysis can reduce the hydrocarbon level of the PW 90 percent effective in ten minutes.

Ma and Wang [85] conducted another analysis on removing organic material from $\mathrm{PW}$ obtained from the oil field by creating large-scale electrochemical stimulation, where they used double anodes with graphite and active metals in addition to minerals and iron as the cathode content. As a catalyst, a noble with a wide surface area. The finding showed a more than 90\% reduction in COD and BOD levels in 6 minutes. Furthermore, in 3 minutes, they observed a 99 percent decrease in suspended solids, a 22 percent decrease in $\mathrm{Ca}^{2+}$ content, a 98 percent decrease in corrosion incidence, and a 99 percent decrease in the presence of sulfates that reduce bacteria.

\subsection{Biological Treatment}

Since aerobic or anaerobic environments are preserved, bioremediation is the least costly way of eliminating contaminants [86]. Furthermore, 0.2-10 micrometer algae, fungi, and bacteria are typically present in produced water and may be used to treat the produced water since these microorganisms use the contaminants as a food source for growing [87]. There are various methods and strategies which can be utilized. for biological treatment of $\mathrm{PW}$, such as series reactors tanks and aerobic biological filters [33].

In biological treatment, four sources of microorganisms have been investigated:

- Microorganisms found in nature

- Commercial Microorganisms

- Specific microorganism communities

- Biodegradable sewage sludge

The most common method for wastewater treatment is activated sludge; the activated sludge treatment unit will maintain a total petroleum hydrocarbon (TPH) removal efficiency of 98-99 percent at the Solids Retention Period (SRT) for 20 days [88].

According to studies by $\mathrm{Li}$ et al. [89], using Basillus sp. under aerobic conditions will remove COD at a concentration of $2600 \mathrm{mg} / 1$ from PW with a 90 percent removal efficiency Furthermore, the microbial group Rhodopseudomonas, Clostridia and Methanosarcina, was used to remove COD from PW anaerobically and reached a performance in the removal of 65 percent. Kose et al. [90] investigated the operating reliability of 
membrane bioreactors (MBRs) for the real produced water treatment. Regardless of the differences in impact content and Solids retention time (SRT), it was discovered that MBR ensures consistent consistency of water that has been treated by removing 80 to 85 percent of COD and 99 percent of hydrocarbons. Furthermore, Naraghi et al. [91] created the microbial spiral electrochemical cell (SMXC) as a fuel cell to enhance treatment of produced water, whereby the anaerobic salineloving microbial culture consortia was used to the organic compound's removal from the feed water of salinity > $200000 \mathrm{mg} / \mathrm{l}$, They accomplished a elimination of 90 percent of the organic matter.

Furthermore, biodegradable organic matter existing in PW using Microbial Capacity Desalination Cell (MCDC) has been effective in removing $6.4 \mathrm{mg} / \mathrm{l}$ of total organic carbon in the bioreactor in addition to material biodegradation [92] . The cumulative soluble quantity is $36 \mathrm{mg} /$ $\mathrm{g}$ carbon of electrode / $\mathrm{h}$. Though, the main drawbacks of biological treatment is the production of a large volume of Sludge from biological processes that necessitates additional treatment, has a lower quality, and takes a longer contact period. Additional disadvantage is the stable substructure of typical biological methods, that necessitate assembly and a long operating period [33].

Five local microalgae species, Chlorella, Monoraphidium, Scenedesmus, Neochloris, and Dictyosphaerium, were tested for their ability to remove contaminants from produced water in the local petroleum industry [93]. It was discovered that microalgae species can be used to treat water from the petroleum industry.

Granular activated carbon (GAC) biologically active filtration (BAF) was investigated for its ability to efficiently extract organic matter and solids from produced water using three GAC media (one consumable and two new) and a mixture of food supplement [94]. The spent GAC quickly adapted to existing biofilms in the produced water, removing up to 92 percent of DOC (81 percent COD) within 24 hours, meaning that BAF can be seen as a pre treatment for desalination.

The performance of microbial fuel cells (MFCs) and microbial capacitive ion extractor cells (MCDCs) in treating water formed from Bakken rock with high levels of dissolved solids and chemical oxygen demand (COD) was compared [95]. MFCs outperformed MCDCs in terms of COD removal, while MCDCs outperformed MFCs in terms of TDS elimination by a factor of two.

Microbes from a biological treatment device for highly saline water were tested in mixed media for heterocyclic nitrification / aerobic denitrification [96] .After one stage, the heterogeneous nitrification / aerobic denitrification process will occur at a high salinity. Microorganism acclimatization, these mixed adaptive cultures had potential application in the treatment of brine liquid wastes.

\section{Conclusion}

Because of the large amounts of water needed to extract and process oil, as well as other amounts of wastewater produced, the oil and gas industry is one of eight industries that consume large amounts of water. Produced Water is water that rises to the surface with oil or gas during the extraction process. It includes underground formation water and injection water collected with fossil fuels during gas and oil production. The amount of produced water exceeds 39.5 million cubic meters per day and includes a number of chemicals, most of which are poisonous, and ways to avoid the environmental 
effects of this form of wastewater include first minimizing it, then reusing it and as a last option discharge it. Pre-treatment is needed in the latter two cases to eliminate the wide range of toxic substances present in the produced water, but however, the regulation only applies to $\mathrm{O} \& \mathrm{G}$ and not to the other harmful products. However, in recent years, there has been a greater emphasis on other potentially dangerous agents and ingredients. The first step in attempting to choose the right treatment methods is to classify the water produced in order to decide its key components. However, when calculating the O\&G of effluent, the value depends not only on the chemical composition of the water, but also on the extraction processes, so this method should be standardized.

The outcome of this characterization will specify, along with the other elements, if physical pre-treatment is needed, whether heat treatment is recommended, and whether chemical dosing can be prevented, and so on, resulting in the characteristics of the produced water with environmental conditions, economic concerns, and regulations. To decide the best way to solve it, a local context is needed. It is also important to understand the principle of non-discharge of liquids, which in effect means preventing the production of contaminants and minimizing waste. As a consequence, after treating the produced water, the safest choice is to reuse it, but there is inadequate regulation in this regard, considering the fact that it seems that more strict controls and requirements are needed. There are a number of treatments for this water, but it is important to understand what needs to be replaced, since most of them concentrate on only one kind of contaminant, and to select the type that uses the least amount of resources and reagents, in order to have the least environmental effects.

\section{Conflict of interest}

The authors declare that there are no conflicts of interest regarding the publication of this manuscript.

\section{References}

1. Lapworth, D. J., Baran N. , Stuart M. E., and Ward,R.S. (2012). "Emerging organic contaminants in groundwater: a review of sources, fate and occurrence," Environ. Pollut., vol. 163, pp. 287-303.

2. Li, Z., Ma, Z. ,van der Kuijp , T. J. Z. Yuan, and Huang, L. (2014). "A review of soil heavy metal pollution from mines in China: pollution and health risk assessment," Sci. Total Environ., vol. 468, pp. 843-853.

3. SHirazi, M. M. A., Kargari, A., Ismail, A. F. and Matsuura,T.(2016). "Computational fluid dynamic (CFD) opportunities applied to the membrane distillation process: State-of-the-art and perspectives," Desalination, vol. 377, pp. 73-90.

4. Abdmouleh, Z., Alammari, R. A. M. and Gastli, A.(2015). "Review of policies encouraging renewable energy integration \& best practices, ” Renew. Sustain. Energy Rev., vol. 45, pp. 249-262.

5. Drioli, E., Ali,A., Lee,Y. M. , Al-Sharif, S. F. , Al-Beirutty, M. and Macedonio, F.(2016). "Membrane operations for produced water treatment," Desalin. Water Treat., vol. 57, no. 31, pp. 1431714335.

6. Abas, N., Kalair, A. and Khan, N.(2015). "Review of fossil fuels and future energy technologies, ” Futures, vol. 69, pp. 31-49.

7. Noureddin, AMMA, Shirazi Tofeily, Kazemi, J. , Motaee, P ., Kargari, E., 
Mostafaei, A., Akia, M., Karout, M., Jaber, A., Hamieh, R. and Tabatabaei, M. (2014). "Accelerated decantation of biodiesel-glycerol mixtures: Optimization of a critical stage in biodiesel biorefinery," Sep. Purif. Technol., vol. 132, pp. 272-280.

8. Çakmakce, M., Kayaalp, N., and Koyuncu, I. (2008). "Desalination of produced water from oil production fields by membrane processes," Desalination, vol. 222, no. 1-3, pp. 176-186.

9. Sowder, J. T., Kelleners, T. J. and Reddy, K. J. (2010). "The Origin and Fate of Arsenic in Coalbed Natural Gas-Produced Water Ponds, ” J. Environ. Qual., vol. 39, no. 5, pp. 1604-1615.

10. Schnabel, B.,Ebrahimi, M.,Schmitz, O.,Kerker,S.,Hild,J.,Gutmann,C.,Aden,M., Liebermann, F. ,Czermak, P.(2013). "Enhanced oil recovery monitoring for oilfield produced water treatment using rotating ceramic membranes,".

11. Chapman, E. C.,Capo, R. C. ,Stewart, B. W., Kirby, C. S., Hammack, R.W., Schroeder, K. T. and Edenborn, H. (2012). "Geochemical and strontium isotope characterization of produced waters from Marcellus Shale natural gas extraction," Environ. Sci. Technol., vol. 46, no. 6, pp. 3545-3553.

12. Alley, B., Beebe, A. , Rodgers Jr, J. and Castle, J. W. (2011). "Chemical and physical characterization of produced waters from conventional and unconventional fossil fuel resources," Chemosphere, vol. 85, no. 1, pp. 74-82.

13. Al-Rubaie, M. S., Dixon, M. A. and Abbas, T. R. (2015). "Use of flocculated magnetic separation technology to treat Iraqi oilfield co-produced water for injection purpose," Desalin. Water Treat., vol. 53, no. 8, pp. 2086-2091.

14. I. E. A. (IEA), (2012). "Iraq energy outlook, "World Energy Outlook.

15. Al-Furaiji, M. H. O., Karim, U. F. A., Augustijn, D. C. M., Waisi, B. I. H. and Hulscher, S. J. M. H. (2016). "Evaluation of water demand and supply in the south of Iraq," J. water reuse Desalin., vol. 6, no. 1, pp. 214-226.

16. Mousa, K. M. and Arafat, S. A. (2015). "Experimental Study on Treatment of Produced Water," J. Chem. Eng. Process Technol., vol. 6, no. 6, p. 1.

17. Allen, D. T. and Rosselot, K. S. (1994). Pollution prevention for chemical processes: A handbook with solved problems from the refining and chemical processing industries. DIANE Publishing.

18. Kusworo, T. D., Aryanti, N. , and Utomo, D. P. (2018). "Oilfield produced water treatment to clean water using integrated activated carbon-bentonite adsorbent and double stages membrane process," Chem. Eng. J., vol. 347, pp. 462-471.

19. L. Arowoshola (2011). "Produced Water Market," Oppor. Oil, Shale Gas Sect. North Am. A Glob. Water Intell. Publ.

20. Dickhout, J. M., Moreno, J., Biesheuvel, P. M. , Boels, L. , Lammertink, R. G. H. and de Vos, W. M. (2017). "Produced water treatment by membranes: a review from a colloidal perspective," J. Colloid Interface Sci., vol. 487, pp. 523-534 .

21. McCabe, P. J. (2020). "Oil and natural gas: global resources,” Foss. Energy, pp. 5-16.

22. Duraisamy, R. T., Beni, A. H. and Henni, A. (2013). "State of the art treatment of produced water," Water Treat., pp. 199222.

23. Arthur, J. D. (2011). "Management of produced water from oil and gas wells," 
Work. Doc. NPC North Am. Resour. Dev. Study Pap., vol. 2, p. 17.

24. Fakhru'l-Razi, A., Pendashteh, A., Abdullah,L. C., Biak, D. R. A., Madaeni,S. S. and Abidin, Z. Z. (2009). "Review of technologies for oil and gas produced water treatment," J. Hazard. Mater., vol. 170, no. 2-3, pp. 530-551.

25. Veil, J. V (2007). "Research to improve water-use efficiency and conservation: Technologies and practice." Washington, DC: US Government Printing Office.

26. Arthur, J., Langhus, B. and Patel, C.(2005). "Technical Summary of Oil \& Gas Produced Water Treatment Technologies," Tulsa, Oklahoma, USA, pp. 1-53.

27. Boysen, D. B., Boysen, J. E. and Boysen, J. A. (2002). "Creative strategies for produced water disposal in the Rocky Mountain Region," 9th Annu. Integr. Environ. Pet. Consortium, Albuquerque.

28. Tao, F. T. (1993) . "Conversion of oilfield produced water into an irrigation/drinking quality water, ".

29. Olsgard F. and Gray, J. S. (1995). “ $A$ comprehensive analysis of the effects of offshore oil and gas exploration and production on the benthic communities of the Norwegian continental shelf," Mar. Ecol. Prog. Ser., vol. 122, pp. 277-306.

30. Davies, J. M., Addy, J. M., Blackman, R. A., Blanchard, J. R., Ferbrache, J. E., Moore, D. C., Somerville, H. J., Whitehead, A. and Wilkinson, T.(1984). "Environmental effects of the use of oilbased drilling muds in the North Sea," Mar. Pollut. Bull., vol. 15, no. 10, pp. 363-370.

31. Veil, J. A., Puder, M. G., Elcock, D. and Redweik Jr, R. J. (2004). “A white paper describing produced water from production of crude oil, natural gas, and coal bed methane.," Argonne National Lab., IL (US).

32. Forbes, V. E., Palmqvist, A. and Bach, L. (2006). "The use and misuse of biomarkers in ecotoxicology," Environ. Toxicol. Chem. An Int. J., vol. 25, no. 1, pp. 272 280.

33. Fakhru'l-Razi, A., Pendashteh, A. , Abdullah, L. C., Biak, D. R. A., Madaeni, S. S. and Abidin, Z. Z. (2009). "Review of technologies for oil and gas produced water treatment," J. Hazard. Mater., vol. 170, no. 2-3, pp. 530-551.

34. Finkel M. L. and Law, L. (2011). "The rush to drill for natural gas: a public health cautionary tale," Am. J. Public Health, vol. 101, no. 5, pp. 784-785.

35. Kassotis, C. D., Tillitt, D. E., Davis, J. W., Hormann, A. M. and Nagel, S. C. (2014). "Estrogen and androgen receptor activities of hydraulic fracturing chemicals and surface and ground water in a drilling-dense region," Endocrinology, vol. 155, no. 3, pp. 897907.

36. Kargbo, D. M., Wilhelm, R. G. ,and Campbell, D. J.(2010). "Natural gas plays in the Marcellus Shale: Challenges and potential opportunities." ACS Publications.

37. Igunnu, E. T. and Chen, G. Z. (2014). "Produced water treatment technologies," Int. J. Low-Carbon Technol., vol. 9, no. 3, pp. 157-177.

38. Daigle, T. and Cox, L. D. (2012). "Ultra deep water discharge of produced water and/or solids at the seabed," Res. Partnersh. to Secur. Energy Am.

39. Spellman, F. R. (2013). Handbook of water and wastewater treatment plant operations. CRC press.

40. Hansen, B. R. and Davies, S. R.(1994). "Review of potential technologies for the 
removal of dissolved components from produced water," Chem. Eng. Res. Des., vol. 72, no. 2, pp. 176-188.

41. Okiel, K., El-Sayed, M. and El-Kady, M. Y.(2011). "Treatment of oil-water emulsions by adsorption onto activated carbon, bentonite and deposited carbon," Egypt. J. Pet., vol. 20, no. 2, pp. 9-15.

42. Luukkonen T. (2014). "Removal of total organic carbon (TOC) residues from power plant make-up water by activated carbon, ” J. Water Process Eng., vol. 3, pp. 46-52.

43. Rawlins, C. H. and Sadeghi, F. (2018). "Experimental Study on oil removal in nutshell filters for produced-water treatment," SPE Prod. Oper., vol. 33, no. 01, pp. 145-153.

44. Kogiso, M. and Aoyagi, M. (2018). "Produced Water Treatment Using Selfassembled Organic Nanotubes as Adsorbents,” J. Japan Pet. Inst., vol. 61, no. 1, pp. 44-49.

45. Akhbarizadeh, R., Moore, F., Mowla, D. and Keshavarzi, B. (2018). "Improved waste-sourced biocomposite for simultaneous removal of crude oil and heavy metals from synthetic and real oilfield-produced water," Environ. Sci. Pollut. Res., vol. 25, no. 31, pp. 3140731420.

46. Mantell, M. E. (2011). "Produced water reuse and recycling challenges and opportunities across major shale plays," in EPA hydraulic fracturing study technical workshop, , vol. 4, no. 9.

47. Consulting A. L. L.(2003). "Handbook on coal bed methane produced water: Management and beneficial use alternatives," Prep. Groundw. Prot. Res. Found. US Dep. Energy, Natl. Pet. Technol. Ofce, Bur. L. Manag.
48. Beyer, A. H., Palmer, L. L. and Stock, J.(1979). "Biological oxidation of dissolved compounds in oilfield-produced water by a pilot aerated lagoon," J. Pet. Technol., vol. 31, no. 02, pp. 241-245.

49. Casaday, A. L.(1993). "Advances in flotation unit design for produced water treatment,".

50. Scholz, M. (2015). "Wetland systems to control urban runoff". Elsevier.

51. Adewumi, M. A., Erb, J. E. and Watson, R. W.(1992). "Initial Design Considerations for a Cost Effective Treatment of Stripper Oil Well Produced Water," in Produced Water, Springer, pp. 511-522.

52. Wathugala, A. G., Suzuki, T. and Kurihara, Y.(1987). "Removal of nitrogen, phosphorus and COD from waste water using sand filtration system with Phragmites australis," Water Res., vol. 21, no. 10, pp. 1217-1224.

53. Cha, Z., Lin, C.-F., Cheng, C.-J. and Hong, P. K. A.(2010). "Removal of oil and oil sheen from produced water by pressure-assisted ozonation and sand filtration," Chemosphere, vol. 78, no. 5, pp. 583-590.

54. Multon, L. M. and Viraraghavan, T.(2006). "Removal of oil from produced water by coalescence/filtration in a granular bed," Environ. Technol., vol. 27, no. 5, pp. 529-544.

55. Xu P. and Drewes, J. E. (2006). "Viability of nanofiltration and ultra-low pressure reverse osmosis membranes for multibeneficial use of methane produced water," Sep. Purif. Technol., vol. 52, no. 1, pp. 67-76.

56. Madaeni, S. S. (1999). "The application of membrane technology for water disinfection," Water Res., vol. 33, no. 2, pp. 301-308. 
57. Judd, S. and Jefferson, B.(2003) "Membranes for industrial wastewater recovery and re-use". Elsevier.

58. Vuthaluru, H. and Znad, H.(2015). "Treatment of oily produced water with low-cost adsorbents and ceramic membrane microfiltration." Curtin University.

59. Hosseini, S. S., Fakharian Torbati, S., Alaei Shahmirzadi, M. A. and Tavangar, T.(2018). "Fabrication, characterization, and performance evaluation of polyethersulfone/TiO2 nanocomposite ultrafiltration membranes for produced water treatment," Polym. Adv. Technol., vol. 29, no. 10, pp. 2619-2631.

60. Kusworo, T. D.(2018). "Evaluation of Integrated modified nanohybrid polyethersulfone-ZnO membrane with single stage and double stage system for produced water treatment into clean water, ” J. Water Process Eng., vol. 23, no. January, pp. 239-249.

61. Anari, Z., Sengupta, A. and Wickramasinghe, S. R. (2018). "Surface oxidation of ethylene chlorotrifluoroethylene (ECTFE) membrane for the treatment of real produced water by membrane distillation,” Int. J. Environ. Res. Public Health, vol. 15, no. 8, pp. 1-14.

62. Abdel-Salam, O. E., Abou Taleb, E. M. and Afify, A. A.(2018). "Electrochemical treatment of chemical oxygen demand in produced water using flow-by porous graphite electrode," Water Environ. J., vol. 32, no. 3, pp. 404-411.

63. Ahmad, T., Guria, C. and Mandal, A. "Optimal synthesis and operation of lowcost polyvinyl chloride/bentonite ultrafiltration membranes for the purification of oilfield produced water, "J. Memb. Sci., vol. 564, pp. 859-877.
64. Ebrahimi, M., Kerker, S., Schmitz, O., Schmidt, A. A. and Czermak, P. (2018) "Evaluation of the fouling potential of ceramic membrane configurations designed for the treatment of oilfield produced water," Sep. Sci. Technol., vol. 53, no. 2, pp. 349-363.

65. Kim, J., Kim, J. and Hong, S.(2018). "Recovery of water and minerals from shale gas produced water by membrane distillation crystallization," Water Res., vol. 129, pp. 447-459.

66. Kim, J. , Kim, J., Kim, J. , and Hong, S. (2018). "Osmotically enhanced dewatering-reverse osmosis (OED-RO) hybrid system: Implications for shale gas produced water treatment," J. Memb. Sci., vol. 554, pp. 282-290.

67. Riley, S. M., Ahoor, D. C., Oetjen, K. and Cath, T. Y. (2018). "Closed circuit desalination of $O \& G$ produced water: An evaluation of NF/RO performance and integrity," Desalination, vol. 442, pp. 5161.

68. Maltos, R. A.(2018). "Produced water impact on membrane integrity during extended pilot testing of forward osmosisreverse osmosis treatment," Desalination, vol. 440, pp. 99-110.

69. Guo, C. (2018) “A combined ultrafiltration-reverse osmosis process for external reuse of Weiyuan shale gas flowback and produced water," Environ. Sci. Water Res. Technol., vol. 4, no. 7, pp. 942-955.

70. Yang, Q., Li, Z., Lv, W. and Wang, H.(2013). "On the laboratory and field studies of removing fine particles suspended in wastewater using minihydrocyclone," Sep. Purif. Technol., vol. 110, pp. 93-100.

71. Sinker, A. (2007). "Produced water treatment using hydrocyclones-theory and 
practical application," in 4th Int. Petroleum Environmental Conference, Houston, USA, pp. 5-9.

72. Nasiri, M. and Jafari, I. (2017). "Produced water from oil-gas plants: A short review on challenges and opportunities," Period. Polytech. Chem. Eng., vol. 61, no. 2, pp. 73-81.

73. Martin, L.(2014). "10 Produced Water Treatment Technologies: Evaluating the Pros and Cons,".

74. Hayes, T.(2004). "The electrodialysis alternative for produced water management, Produced Water, GasTIPS,".

75. Huang, C. P., Dong, C. and Tang, Z.(1993). "Advanced chemical oxidation: its present role and potential future in hazardous waste treatment," Waste Manag., vol. 13, no. 5-7, pp. 361-377.

76. Muruganandham, M.(2014)."Recent developments in heterogeneous catalyzed environmental remediation processes," $\mathrm{J}$. Nanosci. Nanotechnol., vol. 14, no. 2, pp. 1898-1910.

77. Zhai, J., Ma, H., Liao, J., Rahaman, M. H., Yang, Z. and Chen, Z.(2018). "Comparison of Fenton, ultravioletFenton and ultrasonic-Fenton processes on organics and colour removal from pretreated natural gas produced water," Int. J. Environ. Sci. Technol., vol. 15, no. 11, pp. 2411-2422.

78. Andreozzi, M. (2018). "Treatment of saline produced water through photocatalysis using rGO-TiO2 nanocomposites," Catal. Today, vol. 315, pp. 194-204.

79. Li, Z., Huaiyu, Z. and Hill, D. O. (2000). "NH-3-N Removal in Wastewater by Chemical Precipitation and Exploration of Reaction [J]," Chongqing Environ. Sci., vol. 6, p. p17.
80. Liu, C., Zou, B., Rondinone, A. J. and Zhang, Z. J. (2000). "Chemical control of superparamagnetic properties of magnesium and cobalt spinel ferrite nanoparticles through atomic level magnetic couplings," J. Am. Chem. Soc., vol. 122, no. 26, pp. 6263-6267.

81. Zhou, F. S., Zhao, M. F., Ni, W. X. , Dang, Y. S., Pu, C. S. and Lu, F. J. (2000). "Inorganic polymeric flocculent FMA for purifying oilfield produced water: preparation and uses, " Oilf. Chem, vol. 17, pp. 256-259.

82. Gasperi, J., Laborie, B. and Rocher, V. (2012). "Treatment of combined sewer overflows by ballasted flocculation: Removal study of a large broad spectrum of pollutants," Chem. Eng. J., vol. 211, pp. 293-301.

83. Fujishima, A. and Honda, K. (1972). "Electrochemical photolysis of water at a semiconductor electrode," Nature, vol. 238, no. 5358, pp. 37-38.

84. Adams, M., Campbell, I. and Robertson, P. K. J.(2008). "Novel photocatalytic reactor development for removal of hydrocarbons from water," Int. J. Photoenergy, vol. 2008.

85. Ma, H. and Wang, B.(2006). "Electrochemical pilot-scale plant for oil field produced wastewater by $M / C / F e$ electrodes for injection," J. Hazard. Mater., vol. 132, no. 2-3, pp. 237-243.

86. Günther, F.(2000). "Wastewater treatment by greywater separation: Outline for a biologically based greywater purification plant in Sweden," Ecol. Eng., vol. 15, no. 1-2, pp. 139-146.

87. Lu, M., Zhang, Z., Yu, W. and Zhu,W.(2009). "Biological treatment of oilfield-produced water: A field pilot study," Int. Biodeterior. Biodegradation, vol. 63, no. 3, pp. 316-321. 
88. Commission, O.(2005). "Report on discharges spills and emissions from offshore oil and gas installations.".

89. Li, Q., Kang, C. and Zhang, C.(2005). "Waste water produced from an oilfield and continuous treatment with an oildegrading bacterium," Process Biochem., vol. 40, no. 2, pp. 873-877.

90. Kose, B.(2012). "Performance evaluation of a submerged membrane bioreactor for the treatment of brackish oil and natural gas field produced water," Desalination, vol. 285, pp. 295-300.

91. Naraghi, Z. G., Yaghmaei, S., Mardanpour, M. M. and Hasany, M. (2015). "Produced water treatment with simultaneous bioenergy production using novel bioelectrochemical systems," Electrochim. Acta, vol. 180, pp. 535-544.

92. Stoll, Z. A., Forrestal, C., Ren, Z. J. and $\mathrm{Xu}, \mathrm{P}$. (2015). "Shale gas produced water treatment using innovative microbial capacitive desalination cell," J. Hazard. Mater., vol. 283, pp. 847-855.
93. Hakim, M. A. A., Al-Ghouti, M. A., Das, P., Abu-Dieyeh, M., Ahmed, T. A. and Aljabri, H. M. S. J.(2018). "Potential application of microalgae in produced water treatment," Desalination and Water Treatment, vol. 135. pp. 47-58.

94. Riley, S. M., Ahoor, D. C. and Cath, T. Y.(2018). "Enhanced biofiltration of O\&G produced water comparing granular activated carbon and nutrients, "Sci. Total Environ., vol. 640, pp. 419-428.

95. Shrestha, N., Chilkoor, G., Wilder, J. , Ren, Z. J. and Gadhamshetty, V.(2018). "Comparative performances of microbial capacitive deionization cell and microbial fuel cell fed with produced water from the Bakken shale," Bioelectrochemistry, vol. 121, pp. 56-64.

96. Silva, L. C. F. "Effect of salinity in heterotrophic nitrification/aerobic denitrification performed by acclimated microbiota from oil-produced water biological treatment system," Int. Biodeterior. Biodegrad., vol. 130, no. March, pp. 1-7. 